\title{
Mechanisms for Colonic Sodium Transport during Ontogeny: Loss of an Amiloride-Sensitive Sodium Pathway
}

\author{
YIGAEL FINKEL, ANN-CHRISTINE EKLÖF, AND ANITA APERIA
}

Department of Pediatrics, St. Göran's Children's Hospital, Karolinska Institute, Stockholm, Sweden

\begin{abstract}
Net colonic sodium and fluid absorption is higher in suckling and weanling rats than in adult rats. This study was undertaken to investigate the mechanisms behind these differences. In vivo perfusion of the colon was performed in 14- to 80-day-old rats. Net $\mathrm{Na}$ and water uptake decreased exponentially from 14 to 80 days of age. Na uptake was $402 \pm 73 \mu \mathrm{gEq} / \mathrm{min} / \mathrm{g}$ DT in 20-day-old rats and $116 \pm 6 \mu \mathrm{Eq} / \mathrm{min} / \mathrm{g}$ DT in 40 -day-old rats. After amiloride treatment, net $\mathrm{Na}$ transport was reversed to net secretion $(-79 \pm 36 \mu \mathrm{Eq} / \mathrm{min} / \mathrm{g}$ DT) in 20-day-old rats. Amiloride had no effect on the net Na transport in 40-dayold rats. cAMP stimulation significantly increased the net $\mathrm{Na}$ uptake in 20-day-old rats and significantly reduced the net $\mathrm{Na}$ uptake in 80-day-old rats. cAMP did not increase the net uptake in amiloride-treated 20 -day-old rats. We conclude that there are both quantitative and regulatory changes in the pathways for colonic Na transport during development, and we speculate that the large amiloridesensitive sodium uptake in the young colon is adaptive and contributes to the sodium accretion necessary for rapid growth during late postnatal development (Pediatr Res 24: 46-49, 1988)
\end{abstract}

Abbreviations

BW, body weight

DT, dry tissue

The net sodium and water absorption in the large intestine is higher in infant than in adult rats. The absorption decreases exponentially from the age of 14 to the age of 40 days. The sodium and water absorption is higher in 20-day-old rats that have been kept suckling than in 20-day-old rats that have been weaned at the age of 16 days (1). We have so far found no explanation for the high sodium absorption in the large intestine of the infant rat. The absorptive area in relation to dry weight is not higher in young than in adult rats (2). The fractional absorption in the proximal and distal large intestine is approximately the same in young and adult rats.

Herein we have compared the amiloride-sensitive net sodium flux in vivo in young and adult rats. In adult rats studied under basal conditions the amiloride-sensitive net sodium flux contributes only a few percent to the total sodium influx. We found a much larger amiloride-sensitive sodium flux in the young than

Received August 28, 1987; accepted March 1, 1988.

Correspondence Yigael Finkel, M.D., Department of Pediatrics, St. Göran's Children's Hospital, S-112 81 Stockholm, Sweden.

Supported by Grants 03644-16A from the Swedish Medical Research Council and the Medical Research Council of the Swedish Life Insurance Companies. in the adult rats. In adult rats cAMP reduces the net absorption by stimulating secretion. We also compared the effect of cAMP on the net sodium absorption in young and adult rats both with and without amiloride treatment. The results imply that in young rats cAMP stimulates net sodium uptake in the large intestine and that this stimulation is attenuated if $\mathrm{Na}$ entry via the amiloride-sensitive flux is blocked.

\section{MATERIALS AND METHODS}

Experiments were performed in male Sprague-Dawley rats aged 14 to 80 days. Their mean body weights ranged from $30 \mathrm{~g}$ (14 day old) to $350 \mathrm{~g}$ ( 80 day old).

Rats aged 14 and 20 days were kept with lactating dams until the study began. Litter sizes were six to eight rats in all age groups. All rats had free access to solid rat food (R3, EWOS, Södertälje, Sweden) and tap water until the study began. The rats were kept in air-conditioned animal pens, with a 12-h light cycle and a room temperature of $21 \pm 1^{\circ} \mathrm{C}$.

Animal Preparation. The rats were anesthetized with Inactin $80 \mathrm{mg} / \mathrm{kg} / \mathrm{BW}$ intraperitoneal and a tracheostomy was performed. Indwelling catheters were inserted into one carotid and one jugular vein.

During the entire study a continuous infusion with Ringer's solution containing $147 \mathrm{mM} \mathrm{Na}, 4 \mathrm{mM} \mathrm{K}, 2.3 \mathrm{mM} \mathrm{Ca}$, and 155 $\mathrm{mM} \mathrm{Cl}, \mathrm{pH} 6$, at the rate of $1 \%$ of $\mathrm{BW} / \mathrm{h}$ was delivered by infusion pump into the jugular vein. The body temperature was maintained at $37^{\circ} \mathrm{C}$ by an overhead lamp. The abdomen was opened by a midline incision and the colon was cannulated with a polyethylene catheter distal to the cecal colonic junction. A suture proximal to the cecal colonic junction prevented the passage of fluid from the small intestine. The colon was rinsed with warm Ringer's solution (same as intravenous) at the rate of $15-50 \mathrm{ml} / \mathrm{h}$ until the intestinal contents were removed. About $10 \mathrm{ml}$ warm air were then flushed through the colon and a rectal catheter was placed with its tip above the anal sphincter. Ringer's solution with $5 \mathrm{~g} /$ liter $\left[{ }^{14} \mathrm{C}\right]$ polyethylene glycol as the nonabsorbable indicator of the net water transport was then perfused at a constant rate of $15 \mathrm{ml} / \mathrm{min}$, using an infusion pump. After an equilibration period of $30 \mathrm{~min}$ the effluents were collected during three consecutive 20 -min periods. After the perfusion experiment the colon was removed and the fluid carefully emptied by means of a fingertip. The wet weight of the colon was determined and, after $24-48 \mathrm{~h}$ of drying in $100^{\circ} \mathrm{C}$, the dry weight was determined.

Protocols. Theophylline (ACO, Stockholm, Sweden) in Ringer's solution was administered at the rate of $10 \mathrm{mg} / 100 \mathrm{~g} \mathrm{BW} /$ h. Amiloride (MSD, Rahway, NJ) was administered either intravenously in Ringer's solution at the rate of $0.1 \mathrm{mg} / 100 \mathrm{~g} \mathrm{BW}$ bolus dose, and then by $0.24 \mathrm{mg} / 100 \mathrm{~g} \mathrm{BW} / \mathrm{h}$ continuously or 
intraluminally in the perfusate solution at a concentration of $10^{-4}$ M. Dibutyryl cyclic AMP (dBcAMP, Sigma, St. Louis, MO) was administered at the rate of $2 \mathrm{mg} / 100 \mathrm{BW} / \mathrm{h}$ via an indwelling catheter in one femoral artery, placed with the tip above the branching of the mesenteric arteries.

Calculations. The Student's $t$ test was used in the statistical analyses. Values are given as the mean \pm SEM. $p$ values less than 0.05 are considered significant.

\section{RESULTS}

In control rats the net sodium and fluid absorption decreased with increasing age in an exponential fashion (Fig. 1). The net sodium absorption $(\mu \mathrm{Eq} / \mathrm{min} / \mathrm{g}$ DT) decreased from $723.8 \pm$ 207 in 14-day-old rats to $401.8 \pm 73.2$ in 20 -day-old rats, 115.7 \pm 6 in 40 -day-old rats, and $69.4 \pm 30.7$ in 80 -day-old rats. The net water absorption $(\mathrm{ml} / \mathrm{min} / \mathrm{g}$ DT) decreased from $4.72 \pm 1.53$ in 14-day-old rats to $2.63 \pm 0.55$ in 20-day-old rats, $0.81 \pm 0.02$ in 40-day-old rats, and $0.46 \pm 0.22$ in 80-day-old rats.

Intravenous amiloride administration significantly reduced the net sodium and fluid absorption in 20-day-old rats. Indeed, there was a net sodium secretion of $79 \pm 36 \mu \mathrm{Eq} / \mathrm{min} / \mathrm{g}$ DT and a net fluid secretion of $0.59 \pm 0.15 \mathrm{ml} / \mathrm{min} / \mathrm{g}$ DT. In 40-day-old rats amiloride infusion given intravenously reduced the net sodium to $91.4 \pm 4 \mu \mathrm{Eq} / \mathrm{min} / \mathrm{g} \mathrm{DT}$ and the water absorption to $0.6 \pm$ $0.03 \mathrm{ml} / \mathrm{min} / \mathrm{g}$ DT (Fig. 2).

Intraluminal amiloride perfusion at a concentration of $10^{-4} \mathrm{M}$ resulted in a decrease in the net sodium absorption in 20-dayold rats to $69 \pm 13 \mu \mathrm{Eq} / \mathrm{min} / \mathrm{g}$ DT and in the net water absorption to $0.07 \pm 0.03 / \mathrm{ml} / \mathrm{min} / \mathrm{g} \mathrm{DT}$.

Intravenous theophylline treatment resulted in marked increases in the net sodium and the fluid net absorption in 14- and 20-day-old rats (Fig. 3). In 14-day-old rats the net sodium absorption $(\mu \mathrm{Eq} / \mathrm{min} / \mathrm{g}$ DT) increased to $1689 \pm 345$ and in $20-$ day-old rats the net sodium absorption increased to $1003 \pm 65$. The net water absorption $(\mathrm{ml} / \mathrm{min} / \mathrm{g}$ DT) in 14-day-old rats treated with theophylline increased to $13 \pm 1.8$ and in 20-dayold rats to $7.3 \pm 0.5$.

In 40-day-old rats theophylline treatment had no significant effect on the net sodium and fluid absorption. In 80-day-old rats, theophylline treatment significantly reversed the net sodium absorption to net secretion $2.62 \pm 2.06 \mu \mathrm{Eq} / \mathrm{min} / \mathrm{g} \mathrm{DT}$ and the net water absorption to secretion of $0.06 \pm 0.07 \mathrm{ml} / \mathrm{min} / \mathrm{g}$ DT (Fig. 3). Theophylline increases the cellular levels of cAMP by inhibiting the cyclic nucleotide phosphodiesterase. To directly increase the cellular levels of cAMP, we administered dBcAMP, a cAMP analogue that penetrates the cell membrane. When $\mathrm{dBcAMP}$ was administered intraarterially to 14-day-old rats, the net sodium absorption increased significantly to levels almost identical with those observed in theophylline-treated 14-day-old rats (Table 1). In 40-day-old rats $\mathrm{dBcAMP}$ had no significant effect on the net sodium absorption. The effect was not significantly different from that caused by theophylline.

Theophylline did not stimulate the net sodium uptake in 20day-old amiloride-treated rats. The net sodium absorption was significantly lower in the 20-day-old amiloride- and theophyllinetreated rats than in the control rats. In 40-day-old amiloridetreated rats theophylline had no effect on the net colonic sodium transport (Fig. 4).

\section{DISCUSSION}

This study has shown that the high net colonic sodium uptake consistently found in suckling and weanling rats can be attributed to a high net sodium uptake via amiloride-sensitive sodium flux. In the young rat net sodium absorption was almost completely abolished by intravenous amiloride administration. There was also a pronounced decrease in net sodium uptake if the intestinal lumen was exposed to amiloride. In the adult rats only $15 \%$ of the net sodium absorption was inhibited by intravenous amiloride administration. If adult rats are given a low sodium diet, colonic sodium uptake via the amiloride-sensitive pathway in-

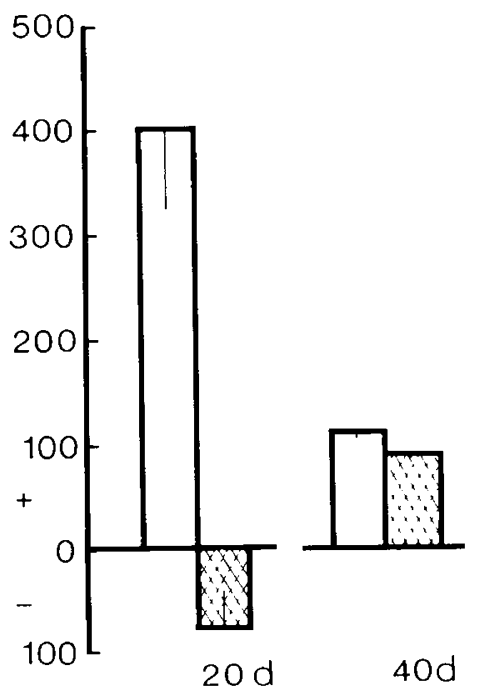

Fig. 2. The effect of amiloride on the net sodium absorption $(\mu \mathrm{Eq} /$ $\mathrm{min} / \mathrm{g} \mathrm{DT}$ ) in 20- and 40-day-old rats. Amiloride was administered intravenously in a bolus dose of $0.1 \mathrm{mg} / 100 \mathrm{~g} \mathrm{BW}$ at the start of the study and then at $0.24 \mathrm{mg} / 100 \mathrm{~g} \mathrm{BW} / \mathrm{h}$ during the study. Each value is the mean \pm SEM in four to six rats. Open bars, controls; hatched bars, amiloride-treated.

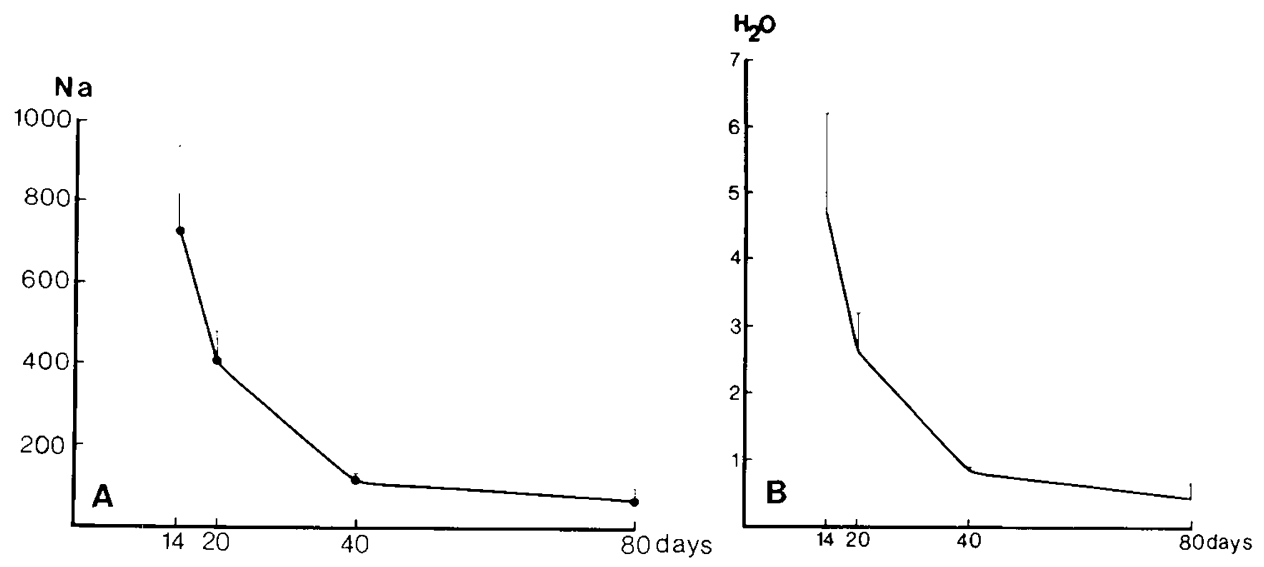

Fig. 1. The net sodium absorption ( $\mu \mathrm{Eq} / \mathrm{min} / \mathrm{g} \mathrm{DT})(l e f t)$ and the net water absorption $(\mathrm{ml} / \mathrm{min} / \mathrm{g} \mathrm{DT})$ (right) in 14- to 80 -day-old control rats. Each value is the mean \pm SEM in six to eight animals. 

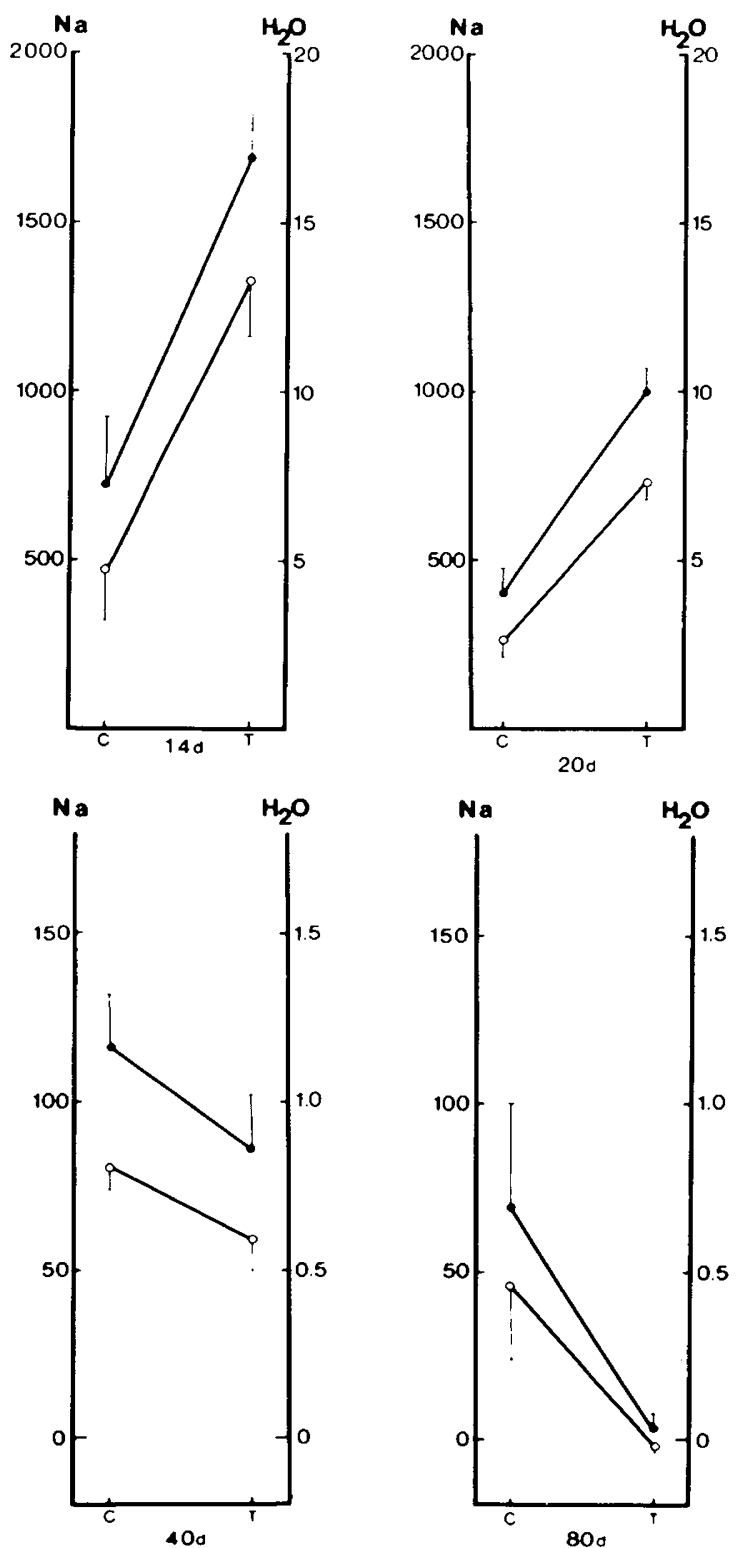

Fig. 3. The effect of theophylline on the net sodium absorption $(\mu \mathrm{Eq} /$ $\mathrm{min} / \mathrm{g} \mathrm{DT}$ ) and the net water absorption $(\mathrm{ml} / \mathrm{min} / \mathrm{g} \mathrm{DT}$ ) in $14-$ to $80-$ day-old rats. Theophylline was administered intravenously at the rate of $100 \mathrm{mg} / \mathrm{kg} \mathrm{BW} / \mathrm{h}$ during the study. Each value is the mean $\pm \mathrm{SEM}$ in five to eight rats. $-\mathrm{Na} ; \mathrm{O}, \mathrm{H}_{2} \mathrm{O}$.

Table 1. Effect of dBCAMP administered intraarterially on the net sodium and fluid absorption in 14- to 40-day-old rats (mean $\pm S E M)$

\begin{tabular}{cccc}
\hline & 14 days & 20 days & 40 days \\
\hline $\mathrm{Na}(\mu \mathrm{Eq} / \mathrm{min} / \mathrm{g} \mathrm{DT})$ & $\begin{array}{c}1683 \pm 161 \\
(n=6)\end{array}$ & $\begin{array}{c}661 \pm 74 \\
(n=4)\end{array}$ & $\begin{array}{c}97 \pm 4 \\
(n=6)\end{array}$ \\
& $\begin{array}{c}12.2 \pm 1.5 \\
\mathrm{H}_{2} \mathrm{O}(\mathrm{ml} / \mathrm{min} / \mathrm{g} \mathrm{DT})\end{array}$ & $\begin{array}{c}4.7 \pm 0.6 \\
(n=4)\end{array}$ & $\begin{array}{c}0.7 \pm 0.03 \\
(n=6)\end{array}$ \\
\hline
\end{tabular}

creases and it has been suggested that in adult rats the amiloridesensitive sodium pathway may represent a sodium scavenger in stress situations, such as hypovolemia or sodium depletion (3).

The mechanisms for regulating transport via the amiloridesensitive pathway are, according to Schultz (4), as follows: 1) modulation of transporter activity by intracellular $\mathrm{Na}$ and/or $\mathrm{Ca}$; 2) short-term regulation of transporter concentration in the

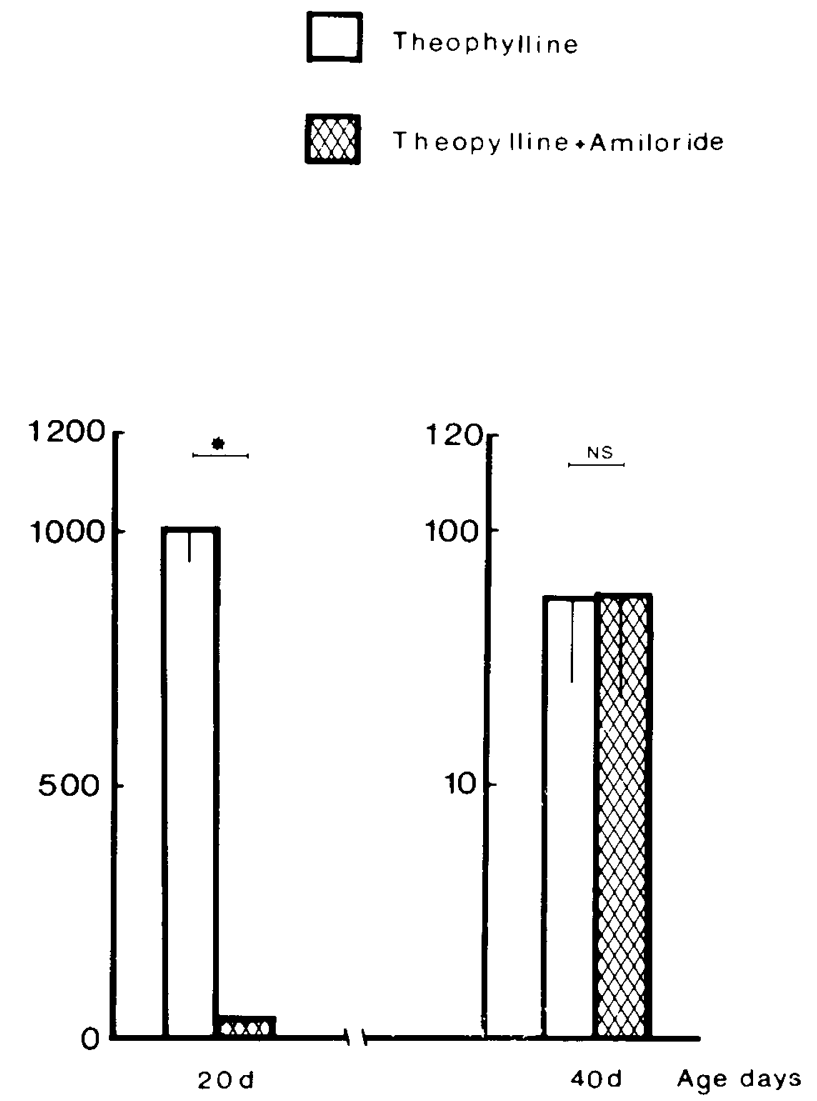

Fig. 4. The effect of concomitant intravenous amiloride and theophylline administration on the net sodium absorption $(\mu \mathrm{Eq} / \mathrm{min} / \mathrm{g} \mathrm{DT})$ in 20- and 40-day-old rats. Amiloride was administered in a bolus dose of $1 \mathrm{mg} / \mathrm{kg} \mathrm{BW}$ at the start of the study and then at the rate of $2.4 \mathrm{mg} /$ $\mathrm{kg} \mathrm{BW} / \mathrm{h}$ during the study. Theophylline was administered in a dose of $100 \mathrm{mg} / \mathrm{kg} \mathrm{BW} / \mathrm{h}$ during the study. Each value is the mean $\pm \mathrm{SEM}$ in four to six rats.

plasma membrane by insertion or retrieval of cytosolic reserve membranes; and 3) new membrane and protein synthesis. Steroid hormones act via the last mentioned type of mechanism (4). Although both glucocorticoids and aldosterone have the potential to stimulate sodium uptake by inducing an amiloride-sensitive pathway in the adult rat colon, aldosterone is generally considered to be the physiological mediator (5).

We have recently demonstrated that in the suckling rat there is a sharp increase in plasma aldosterone levels. Peak levels are reached at the age of 20 days. We have also shown that, if endogenous aldosterone production is stimulated by a low salt intake, the net colonic sodium absorption and NaKATPase activity increase more in young than in adult rats (6).

In neonatal pigs there is a peak in serum aldosterone shortly after birth and canrenoate-an antagonist of aldosterone action-inhibits the normal postnatal increase in sodium transport in the colon of neonatal pigs. Amiloride inhibited part of the sodium uptake in the colon of the neonatal pig (7). It is therefore possible that high circulatory levels of aldosterone and an enhanced end-response to aldosterone contribute to the amiloridesensitive sodium uptake found in colon of normal young rats in this study.

The colon is well recognized as a target tissue for mineralocorticoids (8). In the adult colon aldosterone induces amiloridesensitive sodium transport and an approximately 2 -fold increase in NaKATPase levels (9). This study demonstrates that the amiloride-sensitive sodium transport is present to a larger extent in the young than in the adult colon. It is not unique to find changes in net intestinal transport during ontogeny. Sodiumdependent glucose absorption is present in the fetal but not in 
the adult rat colon (10). In the fetal and newborn rat colon there also seems to be a transepithelial transport of macromolecular proteins that is not present in the adult rat colon (11). The properties of the amiloride-sensitive sodium channel have recently been reviewed (12). Most studies have focused on the mechanism of amiloride inhibition of sodium transport in highresistance epithelia, such as the colon and the frog skin. However, amiloride-sensitive sodium transport is also present in the small intestine of salt-depleted adult rats, but the mechanism of the amiloride effect on this epithelia has not been elucidated (13).

The response to cAMP was different in the infant and the mature colon. In accordance with several previous observations, we noted that cAMP had a net antiabsorptive effect on sodium transport in the adult rat colon. It has been suggested that this antiabsorptive effect is mediated either by the inhibition of coupled sodium/chloride uptake or by stimulation of sodium efflux secondary to chloride secretion $(14,15)$. In young rats we found that elevation of tissue cAMP (accomplished either by theophylline or dBcAMP treatment) stimulated net sodium uptake. The increase in net Na uptake in $\mathrm{dBcAMP}$ and theophylline-treated young rats could be due to stimulation of $\mathrm{Na}$ entry or of pump-mediated $\mathrm{Na}$ out-transport. The latter effect is the most likely alternative. cAMP has not been shown to stimulate the amiloride-sensitive sodium entry pathway (16), but shortterm stimulation of the enzymatic activity of existing $\mathrm{Na}$ KATPase has been demonstrated following elevation of cAMP $(17,18)$. Stimulation of the pump activity should lead to an increase in the $\mathrm{Na}$ uptake. Inasmuch as, however, the turnover of the pump is critically dependent on $\mathrm{Na}$ availability, stimulation of the $\mathrm{Na}, \mathrm{K}$ pump should be attenuated, if the Na supply to the cell is decreased. This would be the case in the amiloridetreated young animals.

Herein we did not record potential differences and unilateral fluxes and it is therefore impossible to draw exact conclusions about sodium fluxes on the epithelial cell membrane level.

The high sodium uptake via the amiloride-sensitive pathway may be of benefit to the young rapidly growing rat. The accretion of body tissue, particularly of bone, is associated with sodium retention. It is likely that the high net sodium absorption in the infant rat colon contributes to the sodium retention needed to establish a positive sodium balance for growth (20).

In summary, this study reveals several important differences between the young and the adult colon with regard to sodium transport mechanisms. In the young colon the net sodium absorption is due to a large amiloride-sensitive net sodium uptake.
cAMP increases the net sodium and water uptake in the young colon and reduces the net sodium and water uptake in the adult solon.

\section{REFERENCES}

1. Finkel Y, Aperia A, Eklöf A-C 1985 Development of colonic fluid and electrolyte transport: influence of weaning pattern. J Pediatr Gastroenterol Nutr 4:457-462

2. Finkel Y, Larsson L 1987 Morphometric and functional studies of proximal and distal colon in young and adult rats. J Pediatr Gastroenterol Nutr 6:454459

3. Will PC, DeLisle RC, Cortright RN, Hopfer U 1981 Induction of amiloridesensitive sodium transport in the intestines by adrenal steroids. Ann NY Acad Sci 372:64-78

4. Schultz SG 1984 A cellular model for active sodium absorption by mammalian colon. Annu Rev Physiol 46:435-451

5. Edelman IS 1978 Candidate mediators in the action of aldosterone on $\mathrm{Na}^{+}$transport, vol 1. In: Hoffman JF (ed) Membrane Transport Processes. New York, Raven Press, New York, pp 125-140

6. Finkel Y, Aperia A 1986 Role of aldosterone for control of colonic NaKATPase activity in weanling rats. Pediatr Res 20:242-245

7. Ferguson DR, James PS, Paterson JYF, Saunders JC, Smith MW 1979 Aldosterone-induced changes in colonic sodium transport occurring naturally during development in the neonatal pig. J Physiol 292:495-504

8. Levitan R, Ingelfinger FJ 1965 Effect of d-aldosterone on salt and water absorption from the intact human colon. J Clin Invest 44:801-808

9. Will PC, Cortright RN, DeLisle RC, Douglas JG, Hopfer U 1985 Regulation of amiloride-sensitive electrogenic sodium transport in the rat colon by steroid hormones. Am J Physiol 248:G124-G132

10. Potter GP, Schmidt KL, Lester R 1983 Glucose absorption by in vitro perfused colon of the fetal rat. Am J Physiol 245:G424-G430

11. Helander HF 1973 Enzyme patterns and protein absorption in rat colon during development. Acta Anat 85:153-176

12. Sariban-Sohraby S, Benos DJ 1986 The amiloride-sensitive sodium channel. Am J Physiol 250:C175-C190

13. Will PC, Cortright RN, Groseclose RG, Hopfer U 1985 Amiloride-sensitive salt and fluid absorption in small intestine of sodium depleted rats. Am J Physiol 248:G133-G141

14. Binder HJ, Filburn C, Volpe B 1975 Bile salt alteration of colonic electrolyte transport: Role of cyclic adenosine monophosphate. Gastroenterology 68:503-508

15. Binder HJ, Rawlins CL 1973 The effect of conjugated dihydroxy bile salts on electrolyte transport in the rat colon. J Clin Invest 52:1460-1466

16. Semrad CE, Chang EB 1987 Calcium-mediated cyclic AMP inhibition of Na$\mathrm{H}$-exchange in small intestine. Am J Physiol 252:C315-C322

17. Kennedy BG, Lever JE 1984 Regulation of NaKATPase activity in MDCK kidney epithelial cell cultures: Role of growth state, cyclic AMP and chemical inducers of dome formation and differentiation. J Cell Physiol 121:51-63

18. Bertorello A, Aperia A 1987 Pertussis toxin modulates dopamine inhibition of NaKATPase activity in rat proximal convoluted tubule segments. In: A Maunsbach (ed) Proceedings of the Fifth International Conference on NaKATPase. Alan R. Liss Inc., New York

19. Aviv A, Kobayashi $\Upsilon$, Higashino H, Bauman JW Jr, Yu SS 1982 Chronic sodium deficit in the immature rat; its effect on adaptation to sodium excess. Am J Physiol 242:E241-E247 